\title{
Determination of Total Phenolic Content and Classification Model of Local Variety Soursop (Annona muricata L.) Leaf Powder in Different Altitudes Using NIR and FTIR Spectroscopy coupled with Chemometrics
}

\author{
Lestyo Wulandari ${ }^{1 *}$, Raden Ajeng Yashinta Nirmala Siswanti ${ }^{1}$ and Ari Satia Nugraha²
}

1. Pharmaceutical Analysis and Chemometrics Research Group, Faculty of Pharmacy, University of Jember, Jember, East Java, Indonesia 68121

2. Drug Utilisation and Discovery Research Group, Faculty of Pharmacy, University of Jember, Jember, East Java, Indonesia 68121

\begin{tabular}{l} 
Info Article \\
\hline Submitted:23-07-2019 \\
Revised: $26-2-2019$ \\
Accepted: $13-3-2019$ \\
*Corresponding author \\
Lestyo Wulandari
\end{tabular}

Email:

lestyowulandari@unej.ac.id

\section{ABSTRACT}

Soursop (Annona muricata L.) leaves have been widely used traditionally to overcome health problems, this is related to its total phenolic content. This study was aimed to determine the classification model and total phenolic content of soursop leaf powder of local varieties, in different altitudes using Near Infrared (NIR) and Fourier-transform Infrared(FTIR) spectroscopy with chemometrics. Local variety soursop leaf samples that have been collected from low land (0-200 meter above sea level (masl)), medium land (201-700 masl) and high land (>700 masl) were prepared and then scanned using NIR and FTIR spectroscophotometers. Furthermore, the NIR spectra data from the samples were used as predictors on the LDA classification model of local and queen varieties soursop leaves to identify the sample varieties. Samples identified as local varieties, whose total phenolic content was determined using a comparative method (UV-Vis spectrophotometry). The highest mean of total phenolic content was observed in samples from medium land (Jember) of $5.72 \%$ w/w Gallic Acid Equivalent (GAE), followed by low land (Bangkalan) 2.95\% w/w GAE and high land (Batu) 1.78\% w/w GAE. NIR and FTIR spectra data belonging to the samples were analyzed by chemometrics qualitatively using LDA, SVM and SIMCA, and quantitatively using PLS, PCR and SVR. The best classification and calibration model are formed from the NIR spectra data, that are the LDA model with an accuracy of $100 \%$ and the PLS model with an R-square calibration value of 0.998071 and RMSEC of 1.2735631 . The LDA and PLS models are applied to the real samples. The results of the sample's total phenolic content determination obtained from the NIR spectroscopy method and UV-Vis spectrophotometry method were then tested with Paired-Samples T Test and it can be concluded that the content obtained from the two methods did not have a significant different.

Keywords:Annona muricata L., total phenolic Content, NIR, FTIR, chemometric

\section{INTRODUCTION}

There are around 2300-2500 species in the Annonaceae family, and soursop (Annonamuricata L.) is one of the ethno-medically important species of this family (Kedari and Khan, 2014). An in vitro tests proved that the antioxidant activity of soursop leaves are stronger than those of Annonasquamosa and Annonareticulata(Baskar, et al., 2006). In Indonesia, soursop leaves are widely used by people for traditional medicine (HHS, 2012). The previous research conducted by Adewole and Ojewole (2009) showed that soursop leaves have antioxidant activity that can inhibit oxidative stress. That antioxidant activity is related to the highest phytochemical content in soursop leaves, namely phenolic compounds(Ibrahim and 
Abdullahi, 2015). There are several factors that affected the phenolic content of a plant, such as variety and altitude (Ginting et al., 2005). In Indonesia, two types of soursop varieties are grown, namely local (slightly sweet fruit sour taste) and queen (sweet fruit). The local and queen can only be identified based on the taste of the fruit, and cannot be identified based on their morphology (Sudjijo, 2014). The previous research conducted by Dewi(2018) and Juniarta (2018) has succeeded in identifying two varieties through its total phenolic content, that local soursop leaves contain a higher total phenolic content than queen soursop leaves. This identification has facilitated through the LDA classification model. Soursop that grows at different altitudes is also difficult to identify if only seen from its morphological form, and research to determine the total phenol content of soursop leaf powder that grows based on its altitude has never been done. Considering the uneven contour of Indonesian land, which are divided into low lands (0-200 masl), medium land (201-700 masl), and High lands (>700 masl) (Rukmana, 2002), this study was conducted to determine the total phenolic content and classification model of soursop leaf powder of local varieties at different altitudes using Near Infrared (NIR) spectroscopy and Fourier Transform Infrared (FTIR) spectroscopy with chemometrics. Qualitative analysis using the classification method chemometrics (LDA, SVM, and SIMCA), while quantitative analysis using the regression method chemometrics (PLS, PCR, and SVR). Infrared spectra combined with the chemometrics method can be used to determine a plant from other plants(Sun, et al., 2010).On the previous study conducted by the author, had succeeded classify medicinal plant extract using NIR spectroscopy coupled with LDA, SVM and SIMCA chemometric models on correct category (100\% accuracy) (Wulandari, et al., 2016).This study was aimed to gain the best calibration and classification models that can determine total phenolic content and classify local soursop powder at different altitudes.

\section{MATERIAL AND METHODS}

The materials used were soursop leaves of local varieties, gallic acid standard (Sigma), FolinCiocalteu reagent (Merck), $\mathrm{Na}_{2} \mathrm{CO}_{3}$, methanol 98\%, and distilled water.

\section{Preparation ofsoursop leaf powder}

The training set and the test set sample of local variety soursop leaf were taken from the
Bangkalan District (low land), Jember district (medium land), and the Batu city (high land). The real sample was taken from the Situbondo district (low land), Lumajang district (medium land), and Bondowoso district (high land). Google Earth Altimeter was used to determine sampling points. The samples were dried at room temperature (omitted from direct sunlight) and were grinded to form a powder followed by sieving with a 100 mesh sieve(Depkes RI, 2008). The gravimetric method was used to determine the water content of powder samples, in which the samples were resticted to $<10 \%$ the moisture content. The moisture content were calculated as followed,

Moisture content $(\%)=\frac{\mathrm{A}-\mathrm{B}}{\mathrm{A}} \quad \mathrm{X} 100 \%$

Where A is the weight of the initial sample (g) and $B$ is the sample weight after drying $(\mathrm{g})$.

\section{AnalysisusingNIRandFTIRspectrophotometer}

All samples and gallic acid standard were scanned by NIR spectrophotometer with five replications per replication of three shots for each sample and FTIR spectrophotometer with three replications for each sample(Lukman, et al., 2016; Rahmawati, et al., 2015), so that the NIR and FTIR spectra data are obtained. Through BRIMROSE (NIR) and OPUS (FTIR) software, each spectra data was codenamed.Gallic spectra data used as a comparison of the total phenolic content in the formation of a calibration model.

\section{Identification of samples variety}

Samples variety were predicted by using spectra data samples from NIR scanning as predictors on the LDA classification model of local and queen soursop (Dewi, 2018) in The Unscrambler X 10.2 software. Samples that had been identified as soursop leaf powder of local varieties can be used for further research process.

\section{Determination of total phenolic content by UV- Vis spectrophotometry method}

The overall sample of leaf powder was weighed $25 \mathrm{mg}$ each and replicated three times in each sample, and was then dissolved in methanol $98 \%$ to $10 \mathrm{~mL}$ followed by 2 fold dilution. The standard gallic acid was weighed as much as $12.5 \mathrm{mg}$ and dissolved methanol to $25 \mathrm{~mL}$, so a gallic acid solution was formed with a concentration of $500 \mathrm{ppm}$. Then, the solution was diluted into a series of concentrations of $5.12 \mathrm{ppm}, 10.24 \mathrm{ppm}, 15.36 \mathrm{ppm}, 20.48 \mathrm{ppm}$, $40.96 \mathrm{ppm}, 51.20 \mathrm{ppm}, 81.92 \mathrm{ppm}$, and $102.4 \mathrm{ppm}$. 
Furthermore, the maximum wavelength and operational time optimization were carried out. The gallic acid standard solution was piped $100 \mu \mathrm{L}$ from each series of concentrations and was added with $500 \mu \mathrm{L}$ Folin-Ciocalteu (1:10v/v water), this solution was then incubate for $6 \mathrm{~min}$, was then added with $400 \mu \mathrm{L} \quad \mathrm{Na}_{2} \mathrm{CO}_{3} \quad(7.5 \% \mathrm{w} /$ vwater $)$ (Keskin-Šašićetal., 2012) and was incubated for 90min of operational time (optimization results). The absorbance of each mixture was measured using a wavelength of $759 \mathrm{~nm}$ (optimization results). The absorbance data and the concentration of gallic acid standard solution were processed into the standard curve of gallic acid to form regression equation of the standard gallic acid solution.

The sample solution was piped $100 \mu \mathrm{L}$ then followed by $500 \mu \mathrm{L}$ Folin-Ciocalteu $(1: 10 \mathrm{v} / \mathrm{v}$ water) addition prior incubation for $6 \mathrm{~min}, 400 \mu \mathrm{L}$ $\mathrm{Na}_{2} \mathrm{CO}_{3}(7.5 \% \mathrm{w} / \mathrm{v}$ water)was added(Keskin-Šašić et al., 2012) and was left for $100 \mathrm{~min}$ operational time for samples from the high lands and $110 \mathrm{~min}$ for samples from the low and medium land (optimization results). Absorbance was measured at $759 \mathrm{~nm}$ (optimization results) using UV-Vis spectrophotometer (Hitachi U-1800). Absorbance value was proceeded in the regression equation gallic acid standard to generate total phenolic content as percentage of $\mathrm{w} / \mathrm{w}$ equivalent gallic acid (\% w/w GAE).

\section{Determination and validation of the classification model}

Samples were scanned using NIR spectrophotometer (Brimrose Corporation Luminar 3070) and FTIR spectrophotometer (Bruker Alpha). The NIR and FTIR spectra data of training set samples were processed using the Unscrambler X 10.2 software. Determination of the classification model was carried out by the LDA, SVM, and SIMCA methods. LDA, SVM, and SIMCA were supervised pattern recognition. This due to the analyst controlled the sample classification in wich the samples were previously group by the analyst and referred as the training set to facilitate the process of determining the classification (Enderle and Weih, 2005; Nurul, 2016).The best classification model indicated by $100 \%$ accuracy, which shows that the original prediction of the model was in accordance with the actual classification. The best classification model selected was then validated by Leave-One-OutCross-Validation (LOOCV) and 2-Fold-CrossValidation (2FCV). LOOCV was done by taking a sample data set from the training set where the data was used as a validation set, while the remaining data was used to form a new model. 2FCV done by using the absorbance of the sample test set as a predictor on the selected model(Wulandari,et al., 2016).

\section{Determination and validation of the calibration model}

The NIR and FTIR spectra data of the training set samples were analyzed quantitatively using PLS, PCR and SVR regression chemometrics through Unscrambler $\mathrm{X} 10.2$ software. The absorbance value of the spectrum data wasused as a $\mathrm{Y}$ value (predictor) combined with the $\% \mathrm{w} / \mathrm{w}$ GAE value from a previously determined sample using the UV-Vis spectrophotometry method. The best calibration model was chosen based on the best predictive ability with the greater R-square value, the smaller the RMSE error value. The best calibration model selected was then validated by Leave-One-Out-Cross-Validation and 2-Fold-CrossValidation(Lukman, et al., 2016).

\section{Selected and validated model applications on real samples}

The selected and validated chemometric model applied to the samples of soursop leaf extract powder outside Bangkalan District, Jember District, and Batu City. Using spectrum data of real samples from Bondowoso District (high land), Lumajang District (medium land), and Situbondo District (low land) with absorbance as predictors for selected models for qualitative analysis (classification based on growing altitude) and quantitative (total phenolic content determination). The results of total phenolic content by UV-Vis spectroscopy method were used as a comparative data in determining total phenolic content(Wulandari etal., 2016). In this study, samples were not used commercial samples, due to insufficient information regarding its altitude of the origin.

\section{Data analysis}

The results of the determination of the total phenolic content of real samples by the NIR method and UV-Vis spectrophotometry were compared through the Paired-Samples T-Test using SPSS 25 trial version. Data analysis was carried out at a confidence level of $99 \%$ with significance or Sig. (2-tailed) 0.005(Santoso, 2018; Wulandari et al., 2016). 
Table I. Samples identity, moisture content, and total phenolic content

\begin{tabular}{|c|c|c|c|c|c|c|}
\hline \multirow{2}{*}{$\begin{array}{l}\text { Sample } \\
\text { Group }\end{array}$} & \multirow{2}{*}{$\begin{array}{c}\text { Code } \\
\text { name }\end{array}$} & \multicolumn{2}{|c|}{ Sampling Location* } & \multirow{2}{*}{$\begin{array}{l}\text { Altitude } \\
\text { (masl)* }\end{array}$} & \multicolumn{2}{|c|}{ Values are mean $\pm S D$ of 3 replications } \\
\hline & & Districts & Sub- District & & $\begin{array}{c}\text { Moisture Content } \\
(\%)\end{array}$ & $\begin{array}{c}\text { Total Phenolic Content } \\
\text { (\% w/w GAE) ** }\end{array}$ \\
\hline Training & BN1 & Bangkalan & Arosbaya & 7 & $4.41 \% \pm 0.045$ & $2.42 \pm 0.012$ \\
\hline \multirow[t]{8}{*}{ Set } & BN2 & & TanjungBumi & 30 & $4.31 \% \pm 0.045$ & $2.81 \pm 0.024$ \\
\hline & BN3 & & Sepulu & 28 & $3.81 \% \pm 0.091$ & $2.81 \pm 0.010$ \\
\hline & JR1 & Jember & Arjasa & 232 & $4.91 \% \pm 0.097$ & $5.39 \pm 0.009$ \\
\hline & JR2 & & Kalisat & 274 & $4.32 \% \pm 0.093$ & $6.68 \pm 0.005$ \\
\hline & JR3 & & Jelbuk & 237 & $3.50 \% \pm 0.057$ & $5.89 \pm 0.009$ \\
\hline & BU1 & Batu & Batu & 1019 & $4.39 \% \pm 0.039$ & $1.79 \pm 0.025$ \\
\hline & BU2 & & Junrejo & 747 & $4.90 \% \pm 0.084$ & $2.22 \pm 0.018$ \\
\hline & BU3 & & Bumiaji & 950 & $3.33 \% \pm 0.051$ & $1.61 \pm 0.016$ \\
\hline \multirow[t]{3}{*}{ Test Set } & TS1 & Bangkalan & Klampis & 38 & $4.41 \% \pm 0.036$ & $3.75 \pm 0.026$ \\
\hline & TS2 & Jember & Batu & 1021 & $4.31 \% \pm 0.064$ & $1.49 \pm 0.026$ \\
\hline & TS3 & Batu & Kalisat & 206 & $3.81 \% \pm 0.043$ & $4.92 \pm 0.017$ \\
\hline Real & SN1 & Bondowoso & Pakem & 1123 & $4.91 \% \pm 0.052$ & $3.36 \pm 0.004$ \\
\hline \multirow{2}{*}{ Sample } & SN2 & Lumajang & Kedungjajang & 202 & $4.32 \% \pm 0.057$ & $5.06 \pm 0.083$ \\
\hline & SN3 & Situbondo & Kapongan & 23 & $3.50 \% \pm 0352$ & $3.63 \pm 0.003$ \\
\hline
\end{tabular}

${ }^{*}$ Google Earth Altimeter; ${ }^{* *}$ Result of UV-Vis spectrophotometry method; masl: meter above sea level

\section{RESULT AND DISCUSSION}

Each of the entire sample were given with an identity (codename, sampling location, and altitude) and moisture content of $<10 \%$ (Tabel I). Water content requirements of $<10 \%$ were intended to eliminate water content interference in determination of the classification model and total phenolic content. According to (Agustina, et al., 2015) the water content of the sample was inversely proportional to the reflectance in, which the higher the water content, the smaller the reflectance produced while the absorbance increased. All samples were identified as local varieties by the LDA soursop variety classification model. The results of NIR and FTIR spectra data (Figure 1) of all samples were used as predictors on the LDA soursop variety classification model. All samples have been identified as local varieties of soursop leaf powder.

\section{Determination of total phenolic content by Uv-} Vis spectrophotometry

The selected wavelength was $759 \mathrm{~nm}$ because it produced the highest absorbance in the standard gallic acid. The operational time for the gallic acid standard was $90 \mathrm{~min}$, low and medium land samples are $110 \mathrm{~min}$, and $100 \mathrm{~min}$ of high land samples. Previously, the operational time was determined so that different operational times for gallic acid and samples were obtained, in order to ensure that the total phenolic content determination was carried out accurately. Operational time was chosen when the absorbance of phenolic compounds from the sample was stable or there was no change, that was when the reaction between phenolic compounds in the sample and the Folin-Ciocalteu had run perfectly(Sari and Ayuchecaria, 2017). Based on the regression equation $y=0.093 x+0.058$ obtained, the total phenolic content was then determined by using the results of absorbance measurements in the solution of soursop leaf powder samples which was previously reacted with Folin-Ciocalteu and $\mathrm{Na}_{2} \mathrm{CO}_{3}$ as values $(\mathrm{x})$. The total phenolic content obtained was interpreted in percentage $\mathrm{w} / \mathrm{w}$ equivalent of gallic acid (\% w/w GAE) (Table I). The mean of total phenolic content of $5.72 \% \mathrm{w} / \mathrm{w}$ GAE belonging to the sample from Jember was the highest when compared to samples from Bangkalan $(2.95 \% \mathrm{w} / \mathrm{w}$ GAE) and Batu $(1.78 \%$ $\mathrm{w} / \mathrm{w}$ GAE). This indicated samples from Jember had the highest potential sources of phenolic compounds.

\section{Determination and validation of the classification model \\ The classification model of LDA, SVM, and SIMCA in this study used three types of categories, namely LOW, MEDIUM, and HIGH categories.}


A

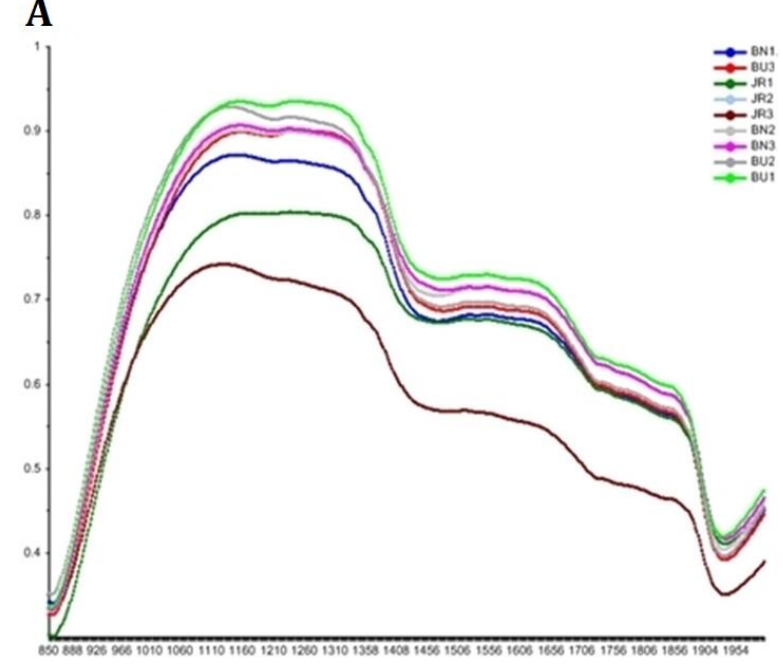

B

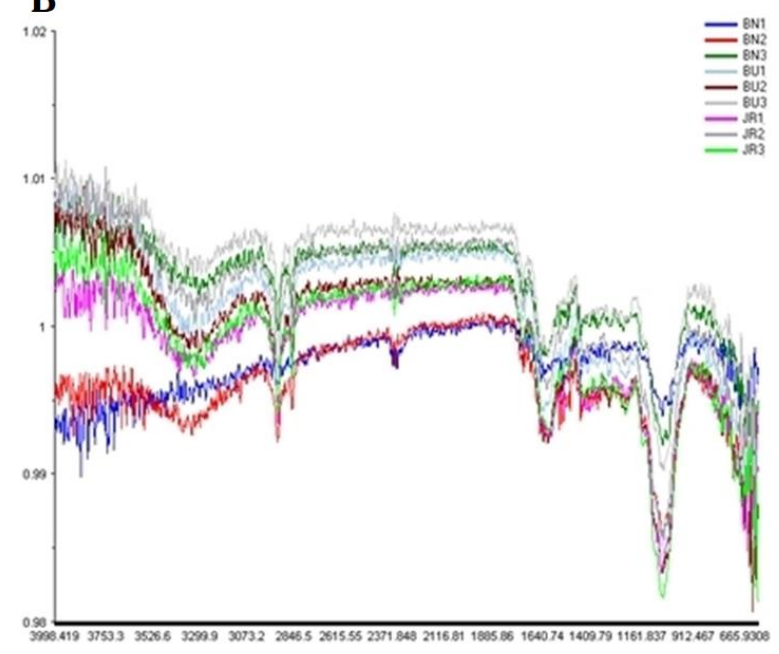

Figure 1. Spectra data A. NIR, B.FTIR of samples in different altitudes (BN1:7 masl; BN2:30 masl; BN3:28 masl; JR1:232 masl; JR2:274 masl; JR3:237 masl; BU1:1019 masl; BU2:747 masl; BU3:950 masl)

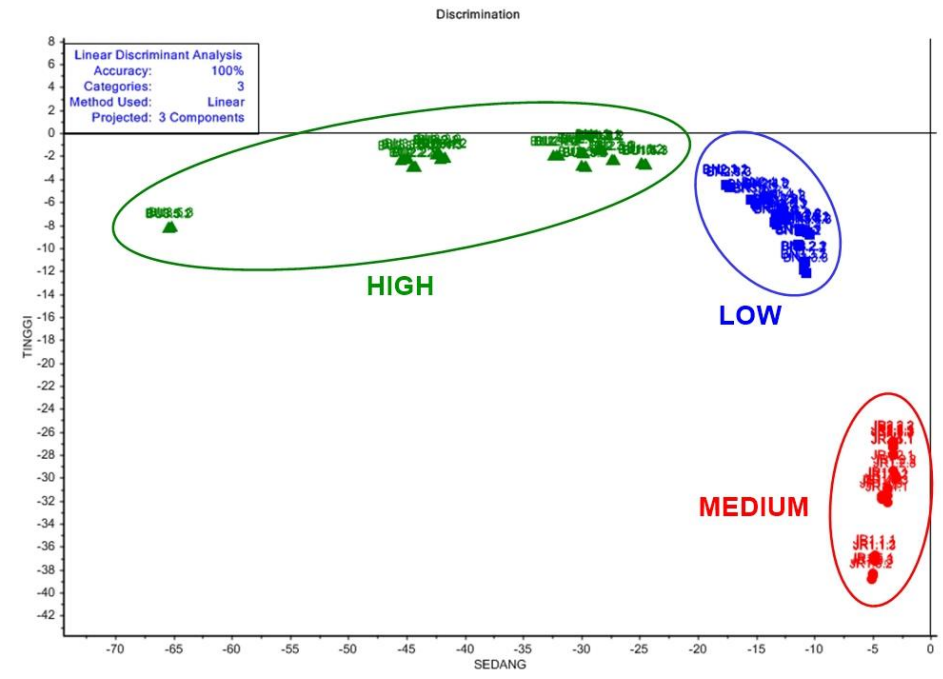

Figure 2. Mapping plot of the LDA model from NIR spectra

The three categories aimed to describe the classification of local varieties of soursop leaf powder based on the altitude of the growing area, which was LOW for samples from the low lands, MEDIUM for samples from the medium lands and HIGH for samples from the high lands (Figure 2). The accuracy of the LDA, SVM, and SIMCA classification models formed from NIR and FTIR spectra data (Table II). It can be seen that the best models were LDA and SVM which were formed from NIR, and also SIMCA spectra which are formed from FTIR spectra with $100 \%$ recognition ability. After cross-validation, the LDA was chosen as the best model because LOOCV and $2 \mathrm{FCV}$ results are $100 \%$, while SVM and SIMCA when crossvalidation were not $100 \%$ accurate.

\section{Determination and validation of the calibration model}

A total of 150 NIR and FTIR spectra data of the training set (samples and gallic acid standards) were analyzed quantitatively using the chemometrics of The Unscrambler $X$ 10.2.The absorbance value of the spectrum data as a $Y$ value (predictor) combined with \% w/w GAE value of the predetermined sample with the UV-Vis 
Table II. The classification ability of the classification model and the results of cross-validation of selected models

\begin{tabular}{|c|c|c|c|c|c|c|}
\hline \multirow{3}{*}{ Model } & \multicolumn{3}{|c|}{ NIR Classification Ability } & \multicolumn{3}{|c|}{ FTIR Classification Ability } \\
\hline & \multirow{2}{*}{ Accuracy (\%) } & \multicolumn{2}{|c|}{$\begin{array}{l}\text { Accuracy of Cross- } \\
\text { Validation (\%) }\end{array}$} & \multirow{2}{*}{ Accuracy (\%) } & \multicolumn{2}{|c|}{$\begin{array}{c}\text { Accuracy of Cross } \\
\text { Validation (\%) }\end{array}$} \\
\hline & & LOOCV & 2FCV & & LOOCV & $2 \mathrm{FCV}$ \\
\hline LDA & 100 & 100 & 100 & 88.89 & - & - \\
\hline SVM & 100 & 100 & 80 & 81.48 & - & - \\
\hline SIMCA & 95.56 & - & - & 100 & 100 & 0 \\
\hline
\end{tabular}

Table III. Results of R-square and RMSE value of the calibration model

\begin{tabular}{cccccc}
\hline Spectra & Model & R-square Calibration & R-square Validation & RMSEC & RMSECV \\
\hline NIR & PLS & 0.998 & 0.9979 & 1.2736 & 1.3133 \\
& PCR & 0.9969 & 0.9967 & 1.6022 & 1.6538 \\
& SVR & 0.9922 & 0.9920 & 3.1012 & 3.1094 \\
FTIR & PLS & 0.9981 & 0.9979 & 1.2736 & 1.3133 \\
& PCR & 0.9969 & 0.9967 & 1.6022 & 1.6538 \\
& SVR & 0.9922 & 0.9920 & 3.1012 & 3.1094 \\
\hline
\end{tabular}

Table IV. The comparison of mean value of $\% \mathrm{w} / \mathrm{w}$ GAE results from the NIR spectroscopic method and the the UV-Vis spectrophotometry method

\begin{tabular}{ccc}
\hline \multirow{2}{*}{ Real Samples } & \multicolumn{2}{c}{ Mean of \% b/b GAE \pm RSD(\%) } \\
\cline { 2 - 3 } & NIR spectroscopic method & UV-Vis spectrophotometry method \\
\hline SN1 Bondowoso & $3.41 \pm 6.65$ & $3.36 \pm 0.129$ \\
SN2 Lumajang & $5.39 \pm 3.92$ & $5.06 \pm 1.64$ \\
SN3 Situbondo & $4.27 \pm 3.44$ & $3.63 \pm 0.088$ \\
\hline
\end{tabular}

spectrophotometry comparison method (Table II) and gallic acid standard (100\% w/w GAE) as the $\mathrm{X}$ (response) in PLS, PCR and SVR regression chemometric methods so that a calibration model was formed. The best calibration model was PLS which was formed from NIR spectra as it had the best R-squared and RMSE value among other calibration models formed (Tabel III). The PLS model has R-square calibration value of 0.998071 and R-square validation value of 0.9979144 . This value indicated the PLS model provided a good regression linearity, which was the actual value, and predictive value composed a closed correlation. PLS model has RMSEC and RMSECV value of 1.2735631 and 1.3132828 , respectively. This value shows that the deviation between the concentrations of the predicted results PLS model againts the actual concentration was minimal compared to the PCR and SVR models, in other words, the formed PLS model successfully predicted the total phenolic content of the sample with the same or close to the actual phenolic content.
The results of the LOOCV PLS model validation showed the R-square and RMSE values obtained were 0.9983148 and 1.2451497 respectively, while the results of $2 \mathrm{FCV}$ validation through the prediction of the test sample showed the R-square and RMSE values of 0.9827973 and 0.2830571 , respectively. Based on the LOOCV and 2FCV validation, it can be concluded that the reliability or consistency of the prediction ability of the PLS calibration model was well-formed in which the model can be implemented in the actual sample.

\section{Selected and validated model applications on real samples}

The absorbance value of the NIR spectra data of the real sample was used as a predictor for the selected and validated model. The LDA classification model predicts all real samples in the right category, so the recognition ability obtained is $100 \%$. The PLS calibration model was used as a quantitative analysis of NIR spectroscopic methods 
for the real samples so that the total phenolic content of each real sample was obtained. The mean value of $\% \mathrm{w} / \mathrm{w}$ GAE results from the NIR spectroscopic method was compared with the results of the UV-Vis spectrophotometry method (Table IV).

Data from the determination of the total phenolic content of the NIR Spectroscopy method and the UV-Vis spectrophotometry method were analyzed by the Paired-Samples T-Test, the purpose of which was to determine whether the results of the total phenolic content of two different methods had the same or identical results. If the Sig. (2-tailed)> 0.005 then the two methods have identical results(Santoso, 2018). Table $\mathrm{V}$ showed analysis results of all real samples with the Sig. (2-tailed)>0.005, which lead to the two methods to have insignificant differences.

Table V. The results of Paired-Samples T-Test of all real samples

\begin{tabular}{cc}
\hline Real Samples & Sig. (2-tailed) \\
\hline SN1 Bondowoso & 0.061 \\
SN2 Lumajang & 0.014 \\
SN3 Situbondo & 0.008 \\
\hline
\end{tabular}

\section{CONCLUSION}

Local varieties of soursop leaves in the medium land (Jember) are the highest source of phenolic compounds, on mean a total phenolic content of $5.72 \% \mathrm{w} / \mathrm{w}$ GAE. NIR spectroscopic methods coupled with LDA and PLS chemometrics can be used to classify local varieties of soursop leaves based on their altitude, that is qualitatively through the LDA classification model and quantitatively through the PLS calibration model to determine the total phenolic content.

\section{ACKNOWLEGEMENT}

The authors are grateful to the financial support of DRPM KemenristekDikti Indonesia, in this research project.

\section{REFERENCES}

Adewole SO., and Ojewole, JAO., 2009. Protective Effects of Annona muricata Linn. (Annonaceae) Leaf Aqueous Extract on Serum Lipid Profiles and Oxidative Stress in Hepatocytes of Spteptozotocin-Treated Diabetic Rats. African J Trad, Comple and Alternative Medicinies, 6(1), 30-41.

Agustina S., Purwanto YA., and Budiastra IW. 2015. Prediksi Kandungan Kimia Mangga
Arumanis selama Penyimpanan dengan Spektroskopi NIR Arumanis Mango Chemical Contents Prediction during Storage using. Jurnal Keteknikan Pertanian, 3(1), 57-63.

Baskar R., Rajeswari V., and Kumar, TS., 2006. In Vitro Antioxidant Studies in Leaves of Annona Species. Indian Journal of Experimental Biology, 45, 480-485.

Depkes RI. 2008. Farmakope Herbal Indonesia (I). Jakarta: Depkes RI.

Dewi MKC. 2018. Penentuan Kandungan Fenolik Total Serbuk Daun Sirsak (Annona muricata L.) Varietas Ratu dan Lokal dan Model Klasifikasi NIR Kemometrik. Skripsi. Jember: Fakultas Farmasi Universitas Jember.

Enderle DIM., and Weih RC. 2005. Integrating Supervised and Unsupervised Classification Methods to Develop a More Accurate Land Cover Classification. J. Arkansas Academy of Science, 59(10), 65-73. https://doi.org/10.1080/10810730903460 526

Ginting E., Widodo Y., Rahayuningsih, SA., and Jusuf, M. 2005. Ginting.pdf. Penelitian Tanaman Pangan, 24(1), 8-18.

Holistic Health Solution (HHS). 2012. Khasiat Fantastis Sirsak vs Srikaya. Jakarta: Grasindo.

Ibrahim NS., and Abdullahi, M. 2015. Cytotoxicity , Total Phenolic Contents and Antioxidant Activity of the Leaves Extract of Annona Muricata. ChemSearch Journal, 6(1), 46-51.

Juniarta IKAA. 2018. Pengembangan Model Klasifikasi dan Penetapan Kadar Fenolat Total Ekstrak Daun Sirsak (Annona muricata L.) Varietas Ratu dan Lokal Menggunakan NIR Kemometrik. Skripsi. Jember: Fakultas Farmasi Universitas Jember.

Kedari TS., and Khan AA. 2014. Guyabano (Annona Muricata): A review of its Traditional uses Phytochemistry and Pharmacology. American Journal of Research Communication, 2(10), 247-268.

Keskin-Šašić, I., Tahirović, I., Topčagić, A., Klepo, L., Salihović, M., Ibragić, S., ... Velispahić, E. 2012. Total Phenolic Content and Antioxidant Capacity of Fruit Juices. Bulletin of the Chemists and Technologists of Bosnia and Herzegovina, 39, 25-28.

Lukman H., Wulandari L., and Retnaningtyas Y. 2016. Penentuan Kadar Flavonoid pada Ekstrak Daun Tanaman Menggunakan Metode NIR dan Kemometrik. Jurnal 
Pustaka Kesehatan, 4(1), 8-13.

Nurul TS. 2016. Unsupervised and Supervised Classification. Retrieved November 19, 2018, from https://titisari04.wordpress.com/2016/11 /04/unsupervised-and-supervisedclassification/

Rahmawati A., Kuswandi B., and Retnaningtyas Y. 2015. Deteksi Gelatin Babi pada Sampel Permen Lunak Jelly Menggunakan Metode Fourier Transform Infra Red (FTIR) dan Kemometrik (Detection of Porcine Gelatin in Jelly Soft Candy Sample Using Fourier Transform Infra Red and Chemometrics). Jurnal Pustaka Kesehatan, 3(2), 278-283.

Rukmana HR. 2002. Usaha Tani Cabai Rawit. Yogyakarta: Kanisius.

Santoso S. 2018. Menguasai Statistik dengan SPSS 25. Jakarta: Elex Media.

Sari AK., and Ayuchecaria, N. 2017. Penetapan Kadar Fenolik Total dan Flavonoid Total
Ekstrak Beras Hitam ( Oryza Sativa L ) dari Kalimantan Selatan. Jurnal Ilmiah Ibnu Sina, 2(2), 327-335.

Sudjijo. 2014. Persamaan antara Varietas Ratu dan Lokal. Retrieved August 1, 2018, from https://balitbu.litbang.pertanian.go.id/inde x.php/hasil-penelitian-mainmenu-46/674persamaan-antara-varietas-sirsak-ratudengan-lokal

Sun SJ., Chen J., Zhou Q., Lu G., and Chan K. 2010. Application of Mid-infrared Spectroscopy in the Quality Control of Traditional Chinese Medicines.PlantaMedica,76(17),1987-1996.

Wulandari L., Retnaningtyas, Y. and Lukman, H. 2016. Analysis of Flavonoid in Medicinal Plant Extract Using Infrared Spectroscopy and Chemometrics. Journal of Analytical Methods in Chemistry, 2016, 1-6. https://doi.org/http://dx.doi.org/10.1155/ 2016/4696803 